\title{
Reduction of islet pyruvate carboxylase activity might be related to the development of type 2 diabetes mellitus in Agouti-K mice
}

\author{
J Han ${ }^{1}$ and $\mathrm{Y} Q$ Liu $^{1,2}$ \\ ${ }^{1}$ The Research Institute for Children, Children's Hospital at New Orleans, 200 Henry Clay Avenue, New Orleans, Louisiana 70118, USA \\ ${ }^{2}$ Department of Pediatrics, Louisiana State University Health Sciences Center, 200 Henry Clay Avenue, New Orleans, Louisiana 70118, USA \\ (Correspondence should be addressed to Y Q Liu at The Research Institute for Children, Children's Hospital at New Orleans; Email: yliu@chnola-research.org)
}

\begin{abstract}
Pyruvate carboxylase (PC) activity is enhanced in the islets of obese rats, but it is reduced in the islets of type 2 diabetic rats, suggesting the importance of $\mathrm{PC}$ in $\beta$-cell adaptation to insulin resistance as well as the possibility that PC reduction might lead to hyperglycemia. However, the causality is currently unknown. We used obese Agouti mice $(\mathrm{AyL})$ as a model to show enhanced $\beta$-cell adaptation, and type 2 diabetic $\mathrm{db} / \mathrm{db}$ mice as a model to show severe $\beta$-cell failure. After comparison of the two models, a less severe type 2 diabetic Agouti-K (AyK) mouse model was used to show the changes in islet PC activity during the development of type 2 diabetes mellitus (T2DM). AyK mice were separated into two groups: mildly (AyK-M, blood glucose $<250 \mathrm{mg} / \mathrm{dl}$ ) and
\end{abstract}

severely (AyK-S, blood glucose $>250 \mathrm{mg} / \mathrm{dl}$ ) hyperglycemic. Islet PC activity, but not protein level, was increased 1.7-fold in AyK-M mice; in AyK-S mice, islet PC activity and protein level were reduced. All other changes including insulin secretion and islet morphology in AyK-M mice were similar to those observed in AyL mice, but they were worse in AyK-S mice where these parameters closely matched those in $\mathrm{db} / \mathrm{db}$ mice. In 2-day treated islets, PC activity was inhibited by high glucose but not by palmitate. Our findings suggest that islet PC might play a role in the development of T2DM where reduction of PC activity might be a consequence of mild hyperglycemia and a cause for severe hyperglycemia.

Journal of Endocrinology (2010) 204, 143-152

\section{Introduction}

Pyruvate carboxylase (PC) is located in the mitochondria and converts carbons from pyruvate derived from glucose into the Krebs cycle intermediate oxaloacetate (MacDonald et al. $1996 a, b)$. The major roles of PC are related to $\beta$-cell adaptation and insulin secretion. Inhibition of PC with its inhibitor phenylacetic acid (PAA) prevents glucose-stimulated insulin secretion (GSIS; Farfari et al. 2000, Liu et al. 2002, 2005). We found that PAA also reduces the $\beta$-cell proliferation response, a portion of adaptation of $\beta$-cell, in $60 \%$ pancreatectomized rats (Liu et al. 2005) and Zucker fatty rats (Liu et al. 2002). We reduced and increased PC activity in primary $\beta$-cells or $\beta$-cell line INS- 1 cells and found that PC down- and up-regulated GSIS in both cell types and cell proliferation in INS-1 cells (Xu et al. 2008). Hasan et al. (2008) used PC siRNA to inhibit PC activity and subsequently inhibit GSIS. ${ }^{13} \mathrm{C}-\mathrm{NMR}$ isotopomer analysis (Lu et al. 2002, Cline et al. 2004) has shown a close correlation between flux through PC and the capacity of glucose to stimulate insulin secretion. In addition, Palmer et al. (2006) found that a single nucleotide polymorphism in the PC gene of African-Americans is significantly associated with the magnitude of the acute insulin response.
Oxaloacetate, a product of $\mathrm{PC}$, enters pyruvate-malate shuttle (MacDonald 1995a, Lu et al. 2002) and pyruvatecitrate shuttle (Khan et al. 1996). These two shuttles play important roles in NADPH production and insulin secretion in the $\beta$-cells (MacDonald 1995a, Khan et al. 1996, Lu et al. 2002). In addition, oxaloacetate can be used for aspartate synthesis (Menendez et al. 1998), and NADPH for lipids and fatty acids synthesis (Infante \& Huszagh 1998, Dmitriev 2001) and anti-apoptosis (Brune et al. 1992, Sheline \& Choi 1998), and importantly for insulin secretion (MacDonald 1995a, 2003).

Pyruvate is also catalyzed into acetyl-CoA (Wallace 1985) in the mitochondria by pyruvate dehydrogenase (PDH; Zhou et al. 1995, 1996). In most cell types, the PDH pathway predominates. However, pancreatic $\beta$-cells express unusually high levels of PC (MacDonald 1995b). As a result, the $\beta$-cell is unique in that approximately equal amounts of pyruvate enter into Krebs cycle via PC and PDH (Khan et al. 1996). A primary role of $\mathrm{PC}$ in tissues such as liver and kidney is to provide substrate for gluconeogenesis (Bahl et al. 1997, Baverel et al. 2003). However, as pointed out by MacDonald (1995a), $\beta$-cells lack the essential gluconeogenic enzyme phosphoenolpyruvate carboxykinase, therefore high levels of $\mathrm{PC}$ are required for a different function in the $\beta$-cells such as 
insulin secretion. On the other hand, entry of pyruvate into the Krebs cycle via PDH does not appear to be important since activation of PDH had only a minor effect on insulin release (Nicholls et al. 2002). We have demonstrated that inhibition of PDH activity by overexpressing pyruvate dehydrogenase kinase 4 in INS- 1 cells could not significantly reduce insulin secretion (Xu et al. 2008).

Type 2 diabetes mellitus (T2DM) is characterized by insulin resistance and $\beta$-cell failure (DeFronzo \& Prato 1996). Once insulin resistance occurs, pancreatic $\beta$-cells must secrete more insulin to maintain normal glucose levels. Increased insulin secretion requires $\beta$-cell adaptation, a process that includes both enhanced insulin secretion and $\beta$-cell proliferation. During compensated obesity, islet PDH activity is reduced while PC activity is unaffected (Liu et al. 2002, 2005), indicating that normal PDH activity is not important for $\beta$-cell adaptation. In T2DM, the failure of $\beta$-cell adaptation coincides with reduced mRNA levels of PC (Jonas et al. 1999, Kjorholt et al. 2005) and activities of PC (MacDonald et al. 1996a,b, 2009) and PDH (Zhou et al. 1995, 1996). These reports suggest that $\mathrm{PC}$, not $\mathrm{PDH}$, plays a key role in the development of T2DM.

However, the cause and effect of reduction of PC activity in the islets of type 2 diabetic mice on hyperglycemia are still unknown. In the current study, we used an obese mouse model (obese Agouti mice, AyL) and two type 2 diabetic mouse models (Agouti-K (AyK) and $\mathrm{db} / \mathrm{db}$ ) to observe the correlation between islet PC activity and hyperglycemic levels during the pathogenesis of T2DM, and tested whether high glucose or fatty acid inhibits PC activity in mouse primary islets.

\section{Materials and Methods}

Animals and blood glucose and plasma insulin assay

Male type 2 diabetic Agouti-KK (AyK, KK background) and control $\mathrm{KK}$ mice, AyL (C57BL/6 background), and control C57BL/6 mice as well as type 2 diabetic $\mathrm{db} / \mathrm{db}$ and control $\mathrm{db} /+$ mice (all were obtained from Jackson Laboratory, Bar Harbor, ME, USA) aged 10-20 weeks were used for this research. The principles of animal laboratory care under the guidelines of both NIH and the University of Louisville and Research Institute for Children's Institutional Animal Care and Use Committees were followed strictly. The mice were maintained at $25^{\circ} \mathrm{C}$ with a $12 \mathrm{~h}$ light: $12 \mathrm{~h}$ darkness cycle. Body weight was determined and blood was collected after tail snipping. Blood glucose was measured with a glucose analyzer (Analox Instruments, Lunenburg, MA, USA). For measuring blood insulin, blood samples were collected in heparinized capillary tubes, and plasma insulin levels were determined with the Ultrasensitive Mouse Insulin-ELISA Test Kit (Mercodia, Uppsala, Sweden).

\section{Glucose tolerance test}

After $3 \mathrm{~h}$ of fasting, mice were administered i.p. $1.0 \mathrm{~g}$ glucose per $\mathrm{kg}$ body weight. Blood glucose levels were determined at $0,15,30,60$, and $120 \mathrm{~min}$, and blood samples were collected (at 0,15 , and 30 min only) to measure plasma insulin levels.

Islet isolation, culture, and high glucose and palmitate treatment

Islets were isolated from the mice by an adaptation of the Gotoh method (Gotoh et al. 1987). Islets were cultured using previous method (Han et al. 2005). For high glucose or palmitate treatment, the islets that were isolated from 10-week-old KK mice were divided into seven groups the next morning, and different concentrations of glucose or palmitate were added to each group. After $48 \mathrm{~h}$ of cultivation, the islets were collected for PC activity assay.

\section{Islet DNA, protein, and insulin contents}

DNA was measured by the Labarca method (Labarca \& Paigen 1980) and protein was measured by a commercial kit that used BSA as a standard (Bio-Rad). Islets were homogenized in acid ethanol and stored at $-20^{\circ} \mathrm{C}$ until assay for insulin contents.

\section{Insulin secretion}

Ten islets were cultured in each $5-\mathrm{ml}$ vial with $1 \mathrm{ml} \mathrm{Krebs-}$ Ringer bicarbonate buffer (KRB supplemented with $10 \mathrm{mmol} / 1$ Hepes, $\mathrm{pH} 7 \cdot 4$, and $0 \cdot 1 \%$ BSA, bubbled with $5 \% \mathrm{CO}_{2}$ and $95 \% \mathrm{O}_{2}$ ) containing $2 \cdot 8,5 \cdot 5$, and $16 \cdot 7 \mathrm{mmol} / 1$ glucose in a $37^{\circ} \mathrm{C}$ shaking water bath as we have described previously (Liu et al. 1998). After incubation for $60 \mathrm{~min}$, vials were moved from water bath to ice to stop the reaction followed by a brief centrifugation at $4{ }^{\circ} \mathrm{C}$, and $0.5 \mathrm{ml} \mathrm{KRB}$ was moved into a glass tube and stored at $-20^{\circ} \mathrm{C}$ until assay for insulin as described above.

\section{$P C$ activity assay and $P C$ protein detection}

PC activity was measured according to the method of MacDonald et al. (1996b). PC protein was detected using the method of MacDonald (1995b) and Xu et al. (2008).

\section{Active PDH activity assay}

Active PDH (aPDH) assay was measured as described previously (Zhou et al. 1995, Liu et al. 1999).

Islet morphology, immunohistochemistry, and $\beta$-cell mass

Immunohistochemistry was carried out as described previously (Jetton et al. 2001, Liu et al. 2002). 
Table 1 General characteristics of 10- and 20-week-old KK, Agouti-K (AyK), C57BL/6, obese Agouti mice (AyL), db/+, and db/db mice. Data are mean \pm S.E.M

\begin{tabular}{|c|c|c|c|c|c|c|}
\hline & \multicolumn{2}{|c|}{ Body weight (g) } & \multicolumn{2}{|c|}{$\begin{array}{l}\text { Three-hour fasting blood glucose } \\
\text { levels }(\mathrm{mg} / \mathrm{dl})\end{array}$} & \multicolumn{2}{|c|}{$\begin{array}{l}\text { Three-hour fasting plasma insulin } \\
\text { levels }(\mathrm{ng} / \mathrm{ml})\end{array}$} \\
\hline & 10 weeks & 20 weeks & 10 weeks & 20 weeks & 10 weeks & 20 weeks \\
\hline \multicolumn{7}{|l|}{ Strains $(n)$} \\
\hline KK (30) & $22 \cdot 3 \pm 1 \cdot 2$ & $32 \cdot 4 \pm 2 \cdot 3$ & $163 \pm 17$ & $171 \pm 15$ & $2 \cdot 8 \pm 0 \cdot 6$ & $3 \cdot 4 \pm 0 \cdot 5$ \\
\hline $\begin{array}{l}\text { AyK-M }(32-40) \\
\quad(<250 \mathrm{mg} / \mathrm{dl})\end{array}$ & $24 \cdot 2 \pm 1 \cdot 1^{*}$ & $37 \cdot 8 \pm 2 \cdot 8^{*}$ & $214 \pm 22^{*}$ & $232 \pm 15^{*}$ & $6 \cdot 5 \pm 1 \cdot 9 *$ & $9 \cdot 9 \pm 1 \cdot 2^{*}$ \\
\hline $\begin{array}{l}\text { AyK-S (10-15) } \\
\quad(>250 \mathrm{mg} / \mathrm{dl})\end{array}$ & $25 \cdot 4 \pm 1 \cdot 6^{*}$ & $39 \cdot 4 \pm 2 \cdot 5^{*}$ & $315 \pm 32^{+, \S}$ & $357 \pm 56^{+, \S}$ & $22 \cdot 3 \pm 2 \cdot 3^{+, \S}$ & $26 \cdot 0 \pm 2 \cdot 6^{+, \S}$ \\
\hline C57BL/6 (30) & $22 \cdot 4 \pm 1 \cdot 3$ & $33 \cdot 6 \pm 2 \cdot 5$ & $165 \pm 15$ & $174 \pm 18$ & $2 \cdot 3 \pm 0 \cdot 7$ & $2 \cdot 8 \pm 0 \cdot 8$ \\
\hline AyL (30) & $24 \cdot 3 \pm 1 \cdot 4$ & $38 \cdot 6 \pm 2 \cdot 1 *$ & $152 \pm 12$ & $165 \pm 13$ & $3 \cdot 2 \pm 1 \cdot 2$ & $3 \cdot 5 \pm 1 \cdot 4^{*}$ \\
\hline $\mathrm{db} /+(30)$ & $23 \cdot 5 \pm 1 \cdot 6$ & $32 \cdot 4 \pm 3 \cdot 3$ & $174 \pm 18$ & $176 \pm 16$ & $2 \cdot 1 \pm 0 \cdot 8$ & $3 \cdot 4 \pm 0 \cdot 7$ \\
\hline $\mathrm{db} / \mathrm{db}(30)$ & $26 \cdot 6 \pm 1 \cdot 7^{*}$ & $44 \cdot 6 \pm 2 \cdot 8^{+}$ & $365 \pm 42^{+}$ & $436 \pm 67^{+}$ & $4 \cdot 5 \pm 1 \cdot 3^{+}$ & $5 \cdot 3 \pm 1 \cdot 5^{+}$ \\
\hline
\end{tabular}

KK means KK mice for control of AyK mice, AyK-M indicates mildly hyperglycemic AyK mice; AyK-S indicates severely hyperglycemic AyK mice, AyL indicates obese mice ( $A^{y}$ gene mutation on $\mathrm{C} 57 \mathrm{BL} / 6$ background), $\mathrm{db} /+$ means littermates without leptin gene mutation and used for control of $\mathrm{db} / \mathrm{db}$ mice, $\mathrm{db} / \mathrm{db}$ indicates $\mathrm{db} / \mathrm{db}$ mice with leptin gene mutation. Weeks indicate age. ${ }^{*} P<0 \cdot 05,{ }^{\dagger} P<0 \cdot 01$ versus parallel controls; ${ }^{\S} P<0 \cdot 01$ versus $A y K-M$ mice.

\section{Data presentation and statistical methods}

All data are expressed as mean \pm s.E.M. The listed $n$ values represent the number of individual experiments performed, and every experiment was duplicated. Comparisons between two groups were performed by Student's $t$-test. Comparisons between multiple groups were performed by one-way ANOVA (Tukey post hoc test). A value of $P<0.05$ was considered significant.

\section{Results}

\section{Mildly and severely hyperglycemic AyK mice}

Hyperglycemia in AyK mice was less severe than that in $\mathrm{db} / \mathrm{db}$ mice; we simply designed a blood glucose value of $250 \mathrm{mg} / \mathrm{dl}$ as a standard point to separate the AyK mice into mildly $(<250 \mathrm{mg} / \mathrm{dl}$, AyK-M) and severely $(>250 \mathrm{mg} / \mathrm{dl}$, AyK-S) hyperglycemic groups. We used this value $(250 \mathrm{mg} / \mathrm{dl})$ to separate the mice because we found that most parameters including insulin secretion and PC activity in isolated islets were significantly changed if blood glucose levels were over $250 \mathrm{mg} / \mathrm{dl}$ and were consistently maintained for over 2 weeks. About $17 \%$ of AyK mice at an age of 10 weeks and $39 \%$ at an age of 20 weeks became severely hyperglycemic respectively. Because of the slow developmental process of severe diabetes, the AyK mice we kept provided an excellent model for investigating the pathogenesis of T2DM. db/db Mice were not ideal for this purpose because they became severely diabetic in a very short period of time: $57 \%$ of $\mathrm{db} / \mathrm{db}$ mice at an age of 6 weeks and $100 \%$ of $\mathrm{db} / \mathrm{db}$ mice at an age of 10 weeks became severely hyperglycemic respectively. However, $\mathrm{db} / \mathrm{db}$ mice would be a good control model for showing severe diabetes.

General characteristics of 10- and 20-week-old $A \gamma K, A \gamma L$, and $\mathrm{db} / \mathrm{db}$ mice

Body weights were measured periodically, and 3-h fasting blood glucose and insulin levels in 10- and 20-week-old AyL, AyK, and $\mathrm{db} / \mathrm{db}$ mice were compared with their parallel normal controls. As shown in Table 1, AyL, AyK-M, AyK-S, and $\mathrm{db} / \mathrm{db}$ mice were obese and had a similar body weight, but $\mathrm{db} / \mathrm{db}$ mice were the heaviest. Compared with control KK mice, glucose and insulin levels of 10- and 20-week-old

Table 2 General characteristics of the islets isolated from 20-week-old KK, Agouti-K (AyK), C57BL/6, obese Agouti mice (AyL), db/+, and $\mathrm{db} / \mathrm{db}$ mice. Data are mean \pm S.E.M

Protein content ( $\mu \mathrm{g} / \mathrm{islet})$

Group $(n=6)$

KK

AyK-M

AyK-S

C57BL/6

AyL

$\mathrm{db} /+$

$\mathrm{db} / \mathrm{db}$

$0 \cdot 72 \pm 0 \cdot 15$
$1 \cdot 35 \pm 0 \cdot 24^{+}$
$1 \cdot 87 \pm 0 \cdot 32^{+}$
$0 \cdot 67 \pm 0 \cdot 18$
$1 \cdot 28 \pm 0 \cdot 25^{+}$
$0 \cdot 75 \pm 0 \cdot 17$
$1 \cdot 66 \pm 0 \cdot 38^{+}$

DNA content (ng/islet)

$20 \cdot 6 \pm 5 \cdot 3$
$48 \cdot 7 \pm 9 \cdot 6^{+}$
$52 \cdot 4 \pm 12 \cdot 4^{+}$
$18 \cdot 9 \pm 4 \cdot 5$
$43 \cdot 6 \pm 9 \cdot 7^{+}$
$22 \cdot 4 \pm 5 \cdot 7$
$46 \cdot 8 \pm 12 \cdot 3^{+}$

Insulin content (ng/islet)
$56 \pm 12$

$115 \pm 38^{+}$

$73 \pm 18^{*, \neq}$

$47 \pm 15$

$152 \pm 32^{+}$

$64 \pm 17$

$35 \pm 9^{\dagger}$
Insulin content $(\mu \mathrm{g} / \mathrm{mg})$

$$
\begin{gathered}
78 \pm 17 \\
85 \pm 28 \\
39 \pm 8^{*, \S} \\
70 \pm 19 \\
117 \pm 26^{*} \\
85 \pm 16 \\
21 \pm 5^{+}
\end{gathered}
$$

${ }^{*} P<0 \cdot 05,{ }^{\dagger} P<0 \cdot 01$ versus parallel controls; ${ }^{\ddagger} P<0 \cdot 05,{ }^{\$} P<0 \cdot 01$ versus AyK-M mice. 

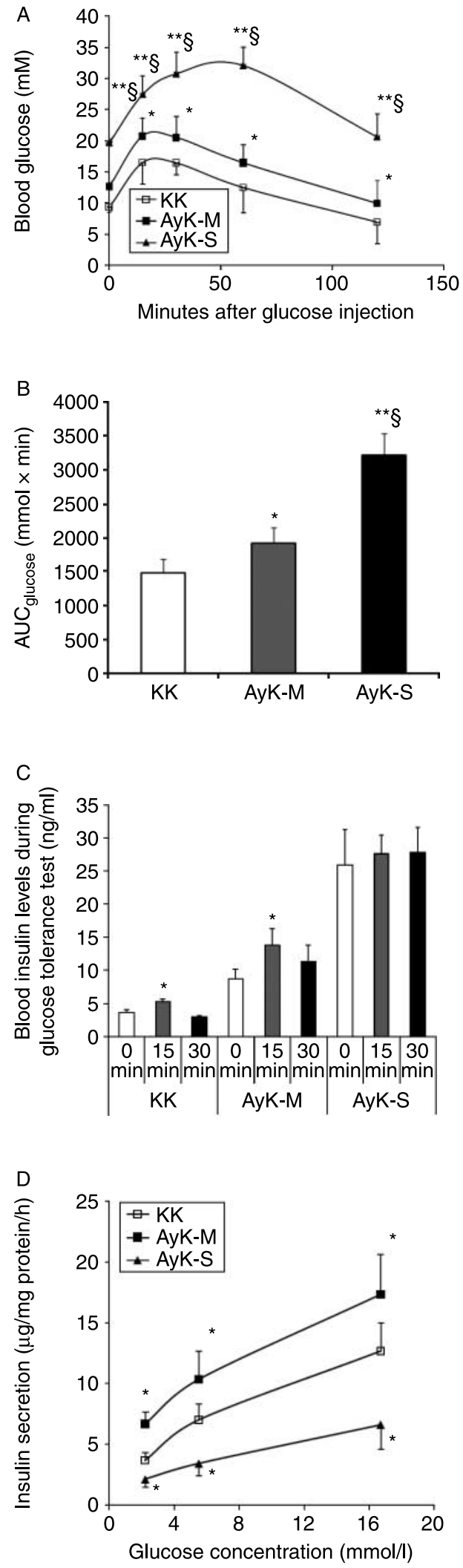

Journal of Endocrinology (2010) 204, 143-152
AyK mice significantly increased, especially in AyK-S mice. Blood glucose levels in $\mathrm{db} / \mathrm{db}$ mice were higher and blood insulin levels were lower than those in AyK-S mice. Islet protein and DNA contents were significantly increased in 20-week-old AyL, AyK-M, AyK-S, and db/db mice (Table 2); however, islet insulin contents in AyK-S and $\mathrm{db} / \mathrm{db}$ mice were markedly reduced, especially in $\mathrm{db} / \mathrm{db}$ mice. In contrast, islet insulin content in AyK-M mice was significantly increased, similar to those in AyL mice. The following results were obtained from 20-week-old mice except the data presented in Fig. 5.

\section{Glucose tolerance tests and plasma insulin levels}

As shown in Fig. 1A, during the course of each time point, the blood glucose levels of AyK-M mice elevated slightly but significantly compared with those of the control KK mice, suggesting the predominance of insulin resistance, but not $\beta$-cell failure. In AyK-S mice, however, blood glucose levels were strikingly elevated at every time point compared to those of either AyK-M or KK mice, indicating that severe insulin resistance and $\beta$-cell failure developed. Figure $3 \mathrm{~B}$ indicates $\mathrm{AUC}_{\text {glucose }}$ for Fig. $1 \mathrm{~A}$; the values are consistent with curve changes shown in Fig. 1A. Fasting blood glucose levels in AyK-S mice were lower than those in $\mathrm{db} / \mathrm{db}$ mice (Table 1), suggesting that diabetes in AyK-S mice was less severe than that in $\mathrm{db} / \mathrm{db}$ mice. We measured plasma insulin levels at 0-, 15-, and 30-min time points during glucose tolerance tests. As shown in Fig. 1C, the highest levels of fasting plasma insulin (0 min) were observed in AyK-S mice; fasting plasma insulin levels in AyK-M mice were also higher than those in the control KK mice. During glucose tolerance tests, similar to KK mice, plasma insulin levels in AyK-M mice at 15 -min time point were significantly increased, indicating that partial $\beta$-cell function in response to high glucose stimulation was preserved. In contrast, AyK-S mice showed no significant change in insulin plasma level at the 15-min time point, suggesting that AyK-S mouse $\beta$-cells lost the responsive capability to glucose stimulation.

\section{Insulin secretion from islets isolated from $A y K$ mice}

To confirm the results of in vivo insulin secretion, we isolated the islets from AyK-M and AyK-S mice and performed in vitro GSIS in the presence of $2 \cdot 8,5 \cdot 5$, and $16 \cdot 7 \mathrm{mmol} / 1$ glucose. As shown in Fig. 1D, compared to control group, islet GSIS was significantly increased in AyK-M mice but it was

Figure 1 Glucose tolerance tests (A), $A \cup C_{\text {glucose }}(B)$, plasma insulin levels during glucose tolerance tests (C), and in vitro GSIS in isolated islets (D) in control $\mathrm{KK}$ and AyK mice. $\mathrm{KK}, \mathrm{KK}$ mice for control of AyK mice; AyK-M, mildly hyperglycemic AyK mice; AyK-S, severely hyperglycemic AyK mice. Data are mean \pm s.E.M. In $(\mathrm{A}$ and $\mathrm{B}), n=8-10, * P<0 \cdot 05, * * P<0 \cdot 01$ versus control KK mice; ${ }^{\S} P<0.01$ versus AyK-M mice. In (C), $n=8-10,{ }^{*} P<0.05$ vs 0 min. In (D), $n=5, * P<0 \cdot 05$ versus control KK mice. 
reduced in AyK-S mice at each glucose concentration, indicating that $\beta$-cell insulin secretory function was significantly enhanced in AyK-M mice but definitely impaired in AyK-S mice. These data are consistent with the in vivo observation (Fig. 1C).

$P C$ and PDH activities in the islets of $A \gamma K-M$ and $A \gamma K-S$ mice

Because of the importance of PC activity described in the Introduction section, we measured PC activity in AyK islets. As shown in Fig. 2A, islet PC activity but not protein expression level significantly increased (1.7-fold) in AyK-M mice; quantified PC protein contents increased by $1 \cdot 3 \pm 0 \cdot 2-$ fold after normalizing to actin $(P<0.05$ versus $\mathrm{KK}$ islets; $n=6$ ), which is not consistent with increased PC activity (1.7-fold increase) but this change may account for the increase in PC activity. In contrast, a reduction in PC activity and protein level was observed in the AyK-S mice. Quantified PC protein contents in AyK-S islets were $45 \pm 8 \%$ of control KK mice after normalizing to actin $(P<0 \cdot 01$ versus KK islets; $n=6)$; this change accounts for the reduction in PC activity. The changes in PC activity in AyK-M islets are consistent with those in an adaptive $60 \%$ pancreatectomized model, where islet PC activity is increased while protein concentration is not (Liu et al. 2005). However, the changes in PC activity in AyK-S islets are similar to those in human severe type 2 diabetic islets, and both Pc mRNA (significantly) and PC activity (slightly) levels are reduced (MacDonald et al. 2009). We measured aPDH activity in AyK islets to know whether the changes in $\mathrm{PDH}$ activity were consistent with those in obese rat islets (Liu et al. 2002). Our data shown in Fig. 2B demonstrate that islet aPDH activity was significantly reduced in both AyK-M and AyK-S mice. These data suggest that islet PC might play a compensatory role in $\beta$-cell adaptation to insulin resistance when $\mathrm{PDH}$ is reduced in AyK-M islets, and reduced islet PC activity in AyK-S mice might be associated with $\beta$-cell failure.

\section{$P C$ and PDH activities and insulin secretion in the islets of $A y L$ and $d b / d b$ mice}

AyL and $\mathrm{db} / \mathrm{db}$ mice were used as control models as described above, thus we measured islet PC and aPDH activities and insulin secretion in these mice. As shown in Fig. 3A, a $2 \cdot 8$-fold increase was observed in PC activity of AyL mice compared to that of C57BL/6 mice. This elevation was higher than that observed in AyK mice (1.7-fold increase, Fig. 2A). Similar to AyK-M islets, PC protein levels in AyL islets were slightly increased; quantified PC protein contents were $1 \cdot 4 \pm 0 \cdot 2$-fold increased after normalizing to actin $(P<0.05$ versus $\mathrm{C} 57 \mathrm{BL} / 6$ islets; $n=6)$, which is not consistent with increased PC activity $(2 \cdot 8 \pm 0 \cdot 4$-fold increase). Similar to AyK-S mice, both PC activity and protein levels in $\mathrm{db} / \mathrm{db}$ mouse islets were significantly reduced (Fig. 3A). Quantified PC protein contents in $\mathrm{db} / \mathrm{db}$ islets were $35 \pm 6 \%$ of control $\mathrm{db} /+$ mice after normalizing to actin $(P<0 \cdot 01$
A
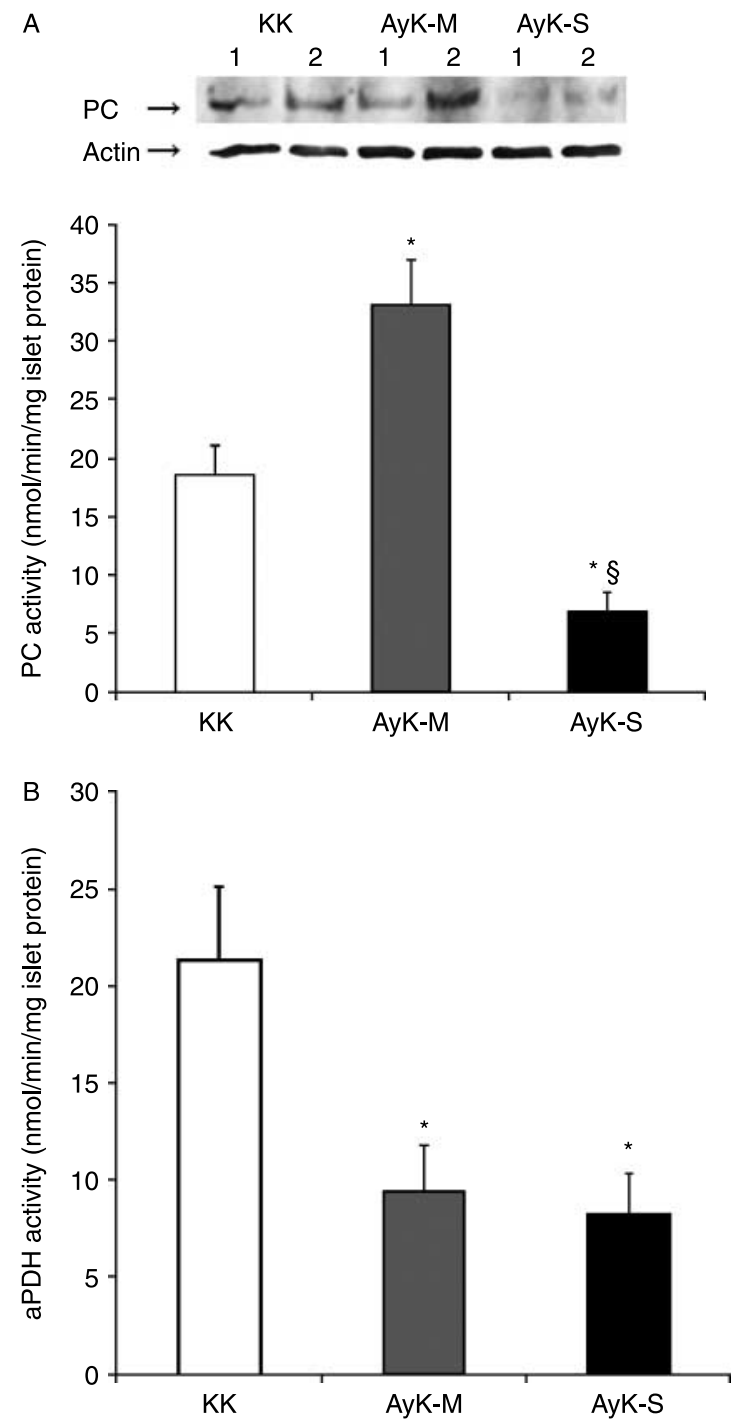

Figure 2 Islet PC activity and protein expression (A) and aPDH (B) activity in 20-week-old $\mathrm{KK}$ and AyK mice. KK, KK mice for control of AyK mice; AyK-M, mildly hyperglycemic AyK mice; AyK-S, severely hyperglycemic AyK mice. Western blot on the top of (A) shows PC protein $(\sim 130 \mathrm{kDa})$ contents and actin. Each lane was loaded with $20 \mu \mathrm{g}$ protein extract obtained from islets isolated from one animal; similar results were obtained in other two independent experiments (total six mice). Quantified PC protein contents are given in the Results section. Data are mean \pm S.E.M. ${ }^{*} P<0 \cdot 01$ versus KK control mice, ${ }^{\S} P<0 \cdot 01$ versus AyK-M mice, $n=6$.

versus $\mathrm{db} /+; n=6)$; this change accounts for the reduction in PC activity. Islet aPDH activity (Fig. 3B) was reduced in both AyL and $\mathrm{db} / \mathrm{db}$ mice, which was similar to that in AyK-M and AyK-S mice (Fig. 2B). Islet GSIS was significantly increased in AyL mice (Fig. 3C), but it was reduced in $\mathrm{db} / \mathrm{db}$ mice (Fig. 3D), and these results were also similar to those observed in AyK-M and AyK-S mice respectively (Fig. 1D). These data demonstrate that the changes in AyK-M islets were similar to 

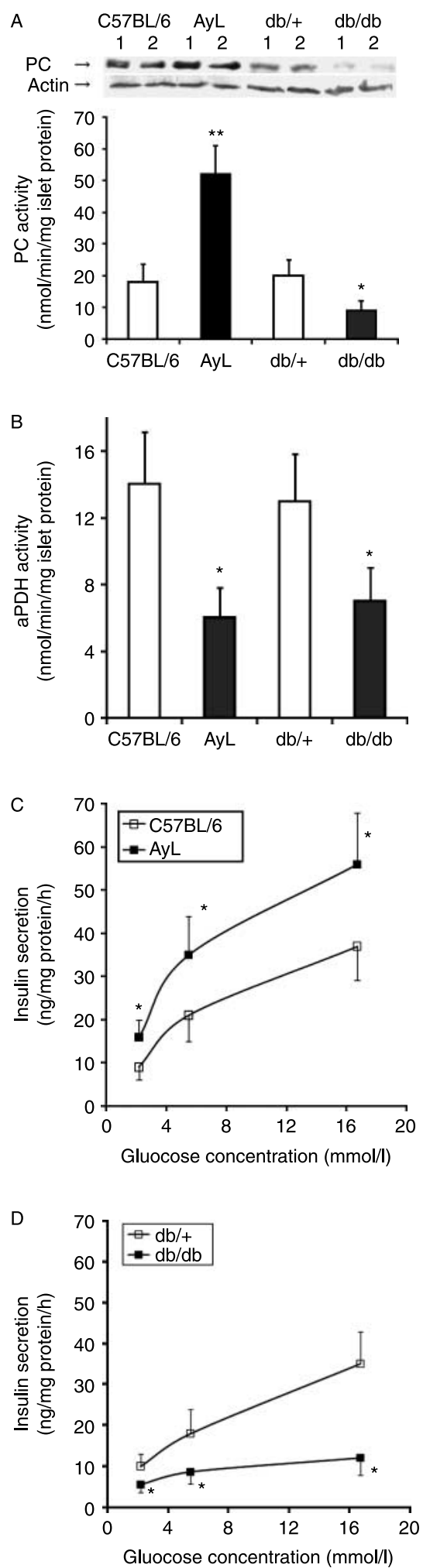

Journal of Endocrinology (2010) 204, 143-152 those in AyL mice, and that the changes in AyK-S mice were similar to those in $\mathrm{db} / \mathrm{db}$ mice. In other words, $\beta$-cell adaptation was enhanced in both AyL and AyK-M mice; $\beta$-cell failure occurred in both AyK-S and $\mathrm{db} / \mathrm{db}$ mice.

Comparison of physiological and biochemical parameters and islet characteristics in six strains of 20-week-old mice

To clearly highlight the importance of PC during the development of T2DM, we have summarized the dynamic changes in insulin resistance, blood glucose levels, PC activity, $\beta$-cell secretory function, and $\beta$-cell mass in Fig. 4 , and these data are compared with islet morphological alterations. We also used C57BL/6 (control of AyL mice) and db/ + (control of $\mathrm{db} / \mathrm{db}$ mice) mice as normal controls, followed by obese AyL, diabetic AyK-M, and AyK-S mice as well as $\mathrm{db} / \mathrm{db}$ mice. The progressive process of T2DM is demonstrated clearly in all groups from normal, obese, mildly diabetic to severely diabetic. Insulin resistance was gradually enhanced starting at obese AyL mice; blood glucose levels were slightly increased in AyK-M mice and further increased in AyK-S mice and $\mathrm{db} / \mathrm{db}$ mice; the latter had the highest blood glucose levels. Interestingly, PC activity was paralleled with $\beta$-cell function and mass, and these three parameters were increased in $\mathrm{AyL}$ mice, indicating that increased PC activity was associated with enhanced $\beta$-cell adaptation. In AyK-M mice, $\beta$-cell function and mass were also enhanced, but these parameters were partially suppressed because of a slight reduction in PC activity compared to that in AyL mice. $\beta$-Cell function and mass were significantly reduced in AyK-S and $\mathrm{db} / \mathrm{db}$ mice, while PC activity was significantly reduced. Importantly, significant reduction in PC activity was also paralleled with the aberrations in islet morphology. All diabetic mice had large islet size. However, islet insulin staining was gradually reduced starting at AyK-M mice, and this change was paralleled with the reduction in PC activity. Islet insulin staining in these mice was consistent with the changes in insulin contents in isolated islets presented in Table 2 . In $\mathrm{db} / \mathrm{db}$ mice, they are supposed to be at an ending stage of T2DM, and most islet insulin staining was lost; in contrast, glucagon staining in the islets was greatly enhanced and aberrant glucagon distribution occurred. Figure 4 demonstrates a strong association between PC activity and $\beta$-cell function/mass and islet morphological aberrations during the pathogenesis of T2DM.

Figure 3 PC activity and protein expression (A), aPDH activity (B) and GSIS (C and D) in isolated islets of 20-week-old C57BL/6, AyL, $\mathrm{db} /+$, and $\mathrm{db} / \mathrm{db}$ mice. C57BL/6 mice were for control of AyL mice; AyL indicates obese (not diabetic) mice on C57BL/6 background; $\mathrm{db} /+$ indicates littermates without leptin gene mutation and used for control of $\mathrm{db} / \mathrm{db}$ mice; and $\mathrm{db} / \mathrm{db}$ indicates $\mathrm{db} / \mathrm{db}$ mice. Western blot on the top of (A) shows PC protein $(\sim 130 \mathrm{kDa})$ contents and actin; each lane was loaded with $20 \mu \mathrm{g}$ protein extract obtained from islets isolated from one animal; similar results were obtained in other two independent experiments (total six mice). Quantified $\mathrm{PC}$ protein contents are given in the Results section. Data are mean \pm s.E.M. ${ }^{*} P<0 \cdot 05,{ }^{* *} P<0 \cdot 01$ versus parallel controls. In $(\mathrm{A}$ and $\mathrm{B}), n=6$; in $(\mathrm{C}$ and $\mathrm{D}), n=4$. 


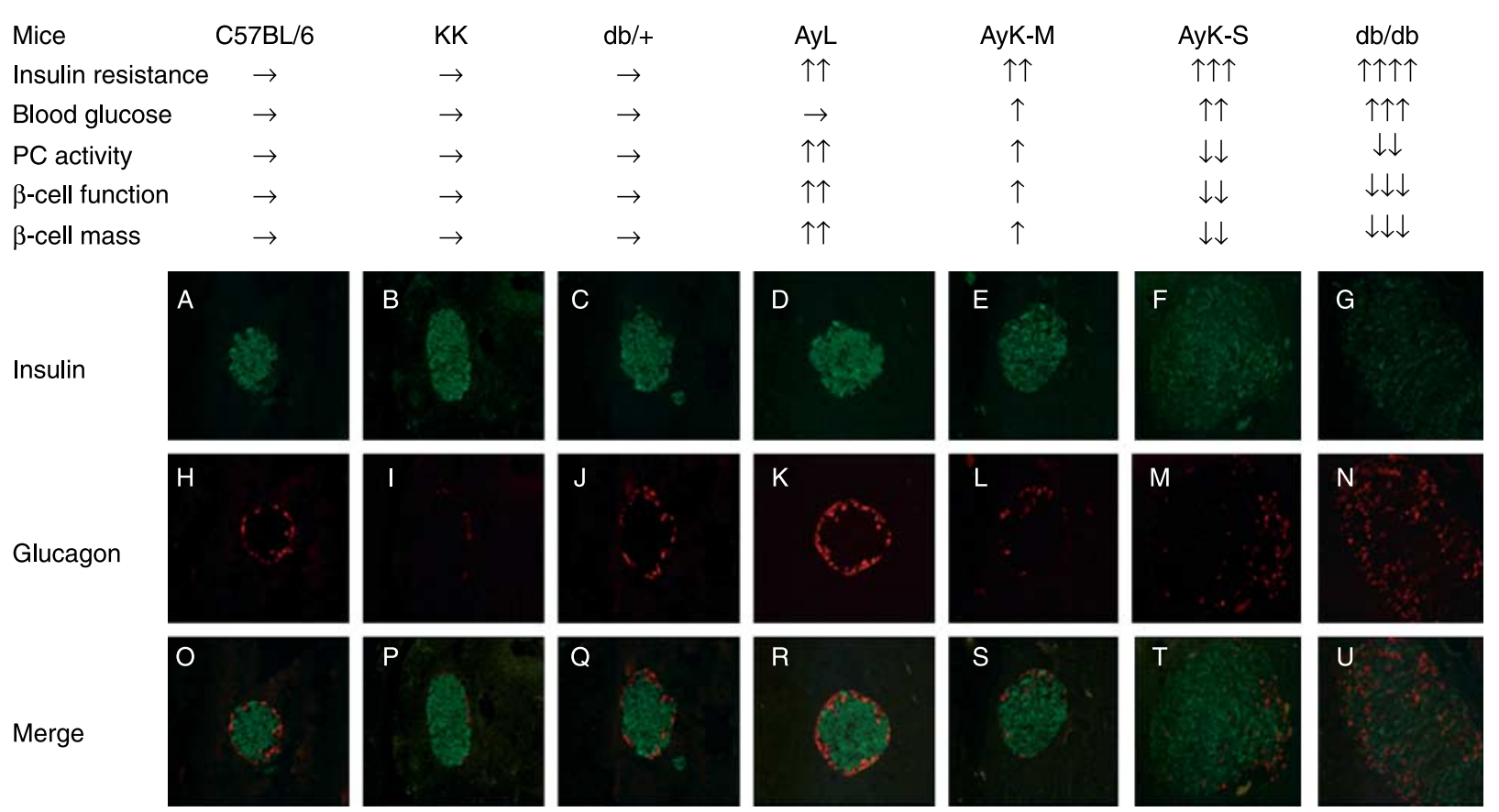

Figure 4 Summary of physiological parameters and islet morphology in seven strains of mice. Physiological and $\beta$-cell mass parameters are summarized on the top. $\rightarrow$ means normal, $\uparrow$ means increase, and $\downarrow$ means decrease, double or more $\uparrow$ or $\downarrow$ means more or much more significant changes. Micrographs $(\mathrm{A}-\mathrm{U}$, magnification $\times 40)$ show insulin $(\mathrm{A}-\mathrm{G})$ and glucagon $(\mathrm{H}-\mathrm{N})$ staining of the typical appearance in the islets of 20-week-old C57BL/6 (A, H, and O), KK (B, I, and P), db/+ (C, J, and Q), AyL (D, K, and R), AyK-M (E, L, and S), AyK-S (F, M, and T), and $\mathrm{db} / \mathrm{db}(\mathrm{G}, \mathrm{N}$, and $\mathrm{U})$ mice. Micrographs from $\mathrm{O}$ to $\mathrm{U}$ are merged of insulin plus glucagon. Each micrograph $(\mathrm{O}-\mathrm{U})$ shows a representative islet taken from a section of separate mouse pancreas. Green color indicates insulin staining, and red color indicates glucagon staining.

\section{PC activity in high glucose and palmitate 2-day treated islets}

Although Fig. 4 demonstrates an association between PC activity level and blood glucose level, the causality remains unknown. We hypothesized that slightly increased blood glucose level might suppress PC activity, because in mildly hyperglycemic AyK-M mice islet PC activity seems to be reduced to $1 \cdot 7$-fold if compared to AyL mice islet PC activity (2.8-fold increased). To test this hypothesis and test what level of hyperglycemia can initially inhibit PC activity, we isolated the islets from 10-week-old KK mice, and treated these islets with different concentrations of glucose for 2 days, and then measured PC activity. We used these mice because they are controls of AyK mice. As shown in Fig. 5A, $\leq 11.1 \mathrm{mmol} / 1$ (equal to $200 \mathrm{mg} / \mathrm{dl}$ ) glucose had no effect on islet PC activity; PC activity was initially suppressed by $12.5 \mathrm{mmol} / 1$ $(225 \mathrm{mg} / \mathrm{dl})$ glucose, and it was significantly reduced by $\geq 13.9 \mathrm{mmol} / 1(250 \mathrm{mg} / \mathrm{dl})$ glucose. Interestingly, fasting blood glucose levels (Table 1) in AyK-M mice were consistent with these glucose concentrations. This result clearly demonstrates that mild hyperglycemia inhibits PC activity in KK mouse islets. To test if high fatty acids contribute to islet $\mathrm{PC}$ reduction, we treated the same islets with palmitate (up to $0.8 \mathrm{mmol} / \mathrm{l}$, bound with BSA) for 2 days. Our data shown in Fig. 5B indicate that 2-day palmitate treatment did not significantly inhibit islet PC activity.

\section{Discussion}

Most data regarding the importance of PC were obtained from rat pancreatic islets (MacDonald et al. 1996a,b, Liu et al. 2002) or rat $\beta$-cell lines (Lu et al. 2002, Cline et al. 2004), and few studies have tested islet PC activity in type 2 diabetic mice. In the current study, we tried to observe whether islet $\mathrm{PC}$ activity is reduced in type 2 diabetic mice. As expected, islet PC activity and protein level were significantly reduced in severely diabetic AyK-S and $\mathrm{db} / \mathrm{db}$ mice, and these results are consistent with those in type 2 diabetic rats (MacDonald et al. 1996a,b) and humans (MacDonald et al. 2009). Surprisingly, islet PC activity and protein concentration in mildly diabetic AyK-M mice were significantly increased (1.7-fold and 1.3-fold respectively). As a distinct compensatory model of obesity, AyL mice have shown a higher level of islet PC activity (2.8-fold, Fig. 3A) compared with C57BL/6 mouse islets. Thus, the elevation of islet PC activity in AyK-M mice may be a portion of enhanced $\beta$-cell adaptation to insulin resistance; reduced islet PC activity and protein level may be related to $\beta$-cell failure in AyK-S and $\mathrm{db} / \mathrm{db}$ mice (Figs 2 and 3), and this observation is consistent with previous reports (MacDonald et al. 1996a,b, 2009). Our recent results (Xu et al. 2008) in PC up- and down-regulated $\beta$-cells support this hypothesis. Although a strong correlation between islet PC activity and hyperglycemia or $\beta$-cell failure 

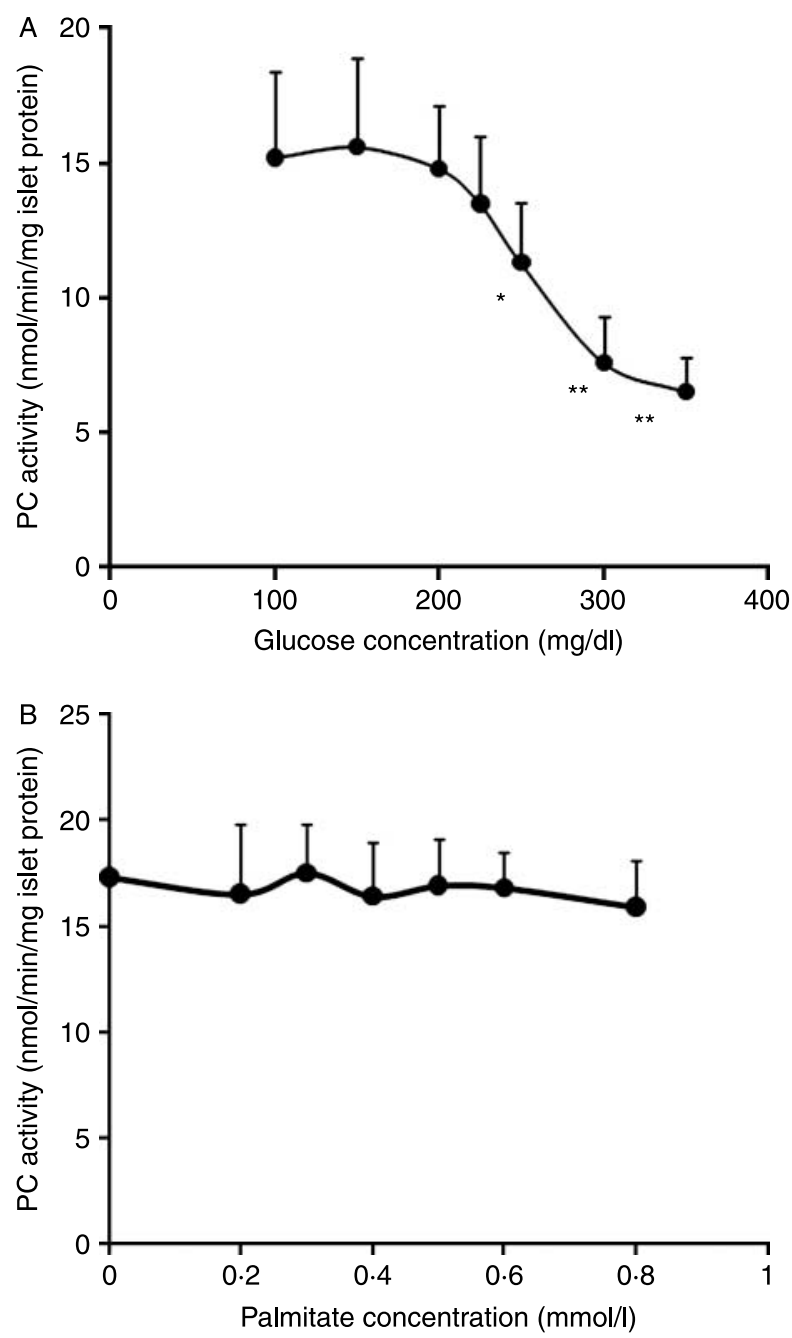

Figure 5 PC activity in high glucose (A) and palmitate (B) 2-day treated islets isolated from 10-week-old KK mice. In (A), glucose was added to each group of the islets to yield 5.5, 8.3, 11.1, 12.5, $13 \cdot 9,16 \cdot 7$, and $19 \cdot 4 \mathrm{mmol} / \mathrm{l}$ (final concentration) respectively, and $5.5 \mathrm{mmol} / /$ glucose-treated group was used as control. In (B), palmitate was added to each group of the islets to yield $0 \cdot 2,0 \cdot 3$, $0 \cdot 4,0.5,0.6$, and $0.8 \mathrm{mmol} / \mathrm{l}$ (final concentration); a control group of islets were not treated with palmitate $(0 \mathrm{mmol} / \mathrm{l})$. All groups of islets in (B) were supplied with $5.5 \mathrm{mmol} / \mathrm{l}$ glucose. Palmitate was dissolved in $10 \%$ fatty acid free-BSA as a stock solution $(8 \mathrm{mmol} / \mathrm{l})$; the latter was diluted with $10 \%$ fatty acid free-BSA to yield different concentrations ( $10 \times$ of final concentration) just before use, and the final concentration of fatty acid free-BSA in the culture medium in all groups including control was $1 \%$. Data are mean \pm s.E.M., $n=4$. In $(\mathrm{A}),{ }^{*} P<0 \cdot 05, * * P<0 \cdot 01$ versus control $(5.5 \mathrm{mmol} / \mathrm{l}$ glucose).

was observed, this correlation, however, did not uncover the causality. In addition, whether PC regulates GSIS is still controversial; Jensen et al. (2006) have observed that $P c$ siRNA did not inhibit GSIS in $\beta$-cell line INS-1 cells, and they have suggested an acetyl carnitine mechanism that compensates for PC inhibition in these cells.

We have known that obesity enhances insulin resistance (White 2003, Shoelson et al. 2006), and the latter can slightly elevate blood glucose levels after a meal challenge compared to noninsulin-resistant individuals (Ahren et al. 1999, Bajaj et al. 2002). Once significant insulin resistance develops, elevated blood glucose is expected to be higher and last for a longer time (Bruning et al. 1997, Gabriely et al. 2002). Compared to frank diabetes, however, this elevation in insulin-resistant individuals is mild (Zhou et al. 1999, Kido et al. 2000). Based on this recognition, we tested whether mild hyperglycemia inhibits islet PC activity. We isolated the islets from $\mathrm{KK}$ mice and treated the islets with different concentrations of glucose, from physiological to diabetic levels. This in vitro study confirmed that mild high glucose $(12.5 \mathrm{mmol} / \mathrm{l}$, equal to $225 \mathrm{mg} / \mathrm{dl})$ initially reduced islet PC activity (Fig. 5A). This result helps us to interpret islet PC activity in AyK-M, AyK-S, and db/db mice. First, in AyK-M mice, islet PC activity was preserved because blood glucose levels were lower than $250 \mathrm{mg} / \mathrm{dl}$ (Table 1; mean values were $214 \mathrm{mg} / \mathrm{dl}$ at 10 weeks of age and $232 \mathrm{mg} / \mathrm{dl}$ at 20 weeks of age). Second, if $2 \cdot 8$-fold increase in islet PC activity in AyL mice is assumed as a 'normal level' for $\beta$-cell adaptation, then 1.7-fold increase in AyK-M islets would be a 'reduced level'. Because $12.5 \mathrm{mmol} / 1$ (equal to $225 \mathrm{mg} / \mathrm{dl}$ ) glucose initially inhibited islet PC activity, a portion of elevated islet PC activity (the values from $1 \cdot 7$-fold to $2 \cdot 8$-fold) in AyK-M mice may be suppressed by mild hyperglycemia $(232 \pm 15 \mathrm{mg} / \mathrm{dl}$, Table 1 ), thus only $1 \cdot 7$-fold increase rather than $2 \cdot 8$-fold increase in PC activity was observed in AyK-M islets. Third, based on the results shown in Fig. 5A, if the levels of glycemia are elevated to or over $13.9 \mathrm{mmol} / 1$ (equal to $250 \mathrm{mg} / \mathrm{dl}$ ), islet PC activity would be significantly inhibited. Because the average value of blood glucose in AyK-S mice was $315 \mathrm{mg} / \mathrm{dl}$ at 10 weeks of age or $357 \mathrm{mg} / \mathrm{dl}$ at 20 weeks of age (Table 1), islet PC activity may be significantly suppressed (Fig. 2A)

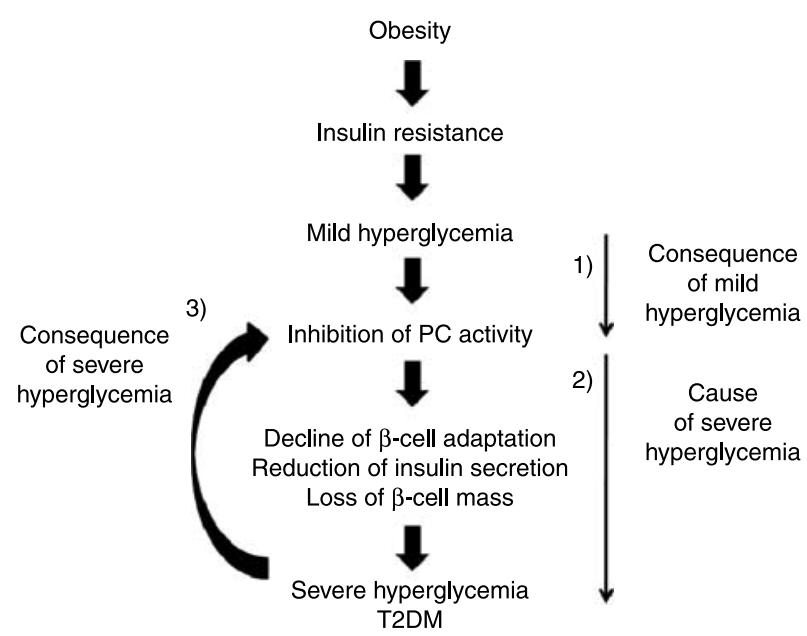

Figure 6 Hypothetic scheme for islet PC activity as a consequence and cause of hyperglycemia during the pathogenesis of T2DM. 1) indicates that mild hyperglycemia leads to an inhibition in PC activity in the islets; 2 ) indicates that the inhibition of islet PC activity works as a cause of severe hyperglycemia; and 3) indicates that severe hyperglycemia in turn inhibits islet PC activity. 
by higher levels of glycemia. Low islet PC activity in $\mathrm{db} / \mathrm{db}$ mice (Fig. 3A) may also be explained by the same mechanism described above. Fourth, because PC has been demonstrated to be important in $\beta$-cell adaptation to insulin resistance and in insulin secretion (Liu et al. 2002, 2005, Xu et al. 2008), inhibited islet PC activity might contribute to $\beta$-cell failure; thus, severe hyperglycemia caused by $\beta$-cell failure would in turn suppress islet PC activity. This hypothesis is supported by the result shown in Fig. 5A, where high glucose (16.7 or $19 \cdot 4 \mathrm{mmol} / \mathrm{l}$, equal to 300 or $350 \mathrm{mg} / \mathrm{dl}$ respectively) significantly reduced islet PC activity; this may explain PC reduction in AyK-S and $\mathrm{db} / \mathrm{db}$ mice (Table 1, Figs $2 \mathrm{~A}$ and $3 \mathrm{~A})$. Although our data can partially explain the inhibition of PC activity by hyperglycemia in diabetic mouse islets, and this is consistent with previous report in rat islet research (Liu et al. 2004), the 'real' mechanisms by which hyperglycemia inhibits PC activity are entirely unknown, thus further efforts are needed to reveal the 'real' mechanisms.

Because high levels of free fatty acids (FFAs) are also present in obese individuals (Unger 1995, Liu et al. 2002), they may be a factor to inhibit islet PC activity. Actually, Busch et al. (2002) have found that treating mouse cancer cell line MIN6 cells with palmitate and oleate for $48 \mathrm{~h}$ resulted in a $2 \cdot 2$ - and 1.8-fold reduction in Pc mRNA respectively. Our data, however, demonstrated that palmitate (up to $0.8 \mathrm{mmol} / \mathrm{l}$ ) did not inhibit PC activity in 2-day treated KK mouse primary islets (Fig. 5B), and these results were consistent with our previous observation in rat islets (Liu et al. 1999, $\mathrm{Xu}$ et al. 2006). Compared with high glucose, FFA may not be a key factor to inhibit PC activity in 2-day treated mouse primary islets.

If $\mathrm{AyL}$ and $\mathrm{db} / \mathrm{db}$ mice are considered as pre-diabetic and severely diabetic respectively, diabetic states in AyK-M and AyK-S mice would be in the early-middle and late-middle stages of the pathogenesis of T2DM. The islet micrographs shown in Fig. 4 clearly demonstrate that AyK-M and AyK-S mice stay on the way between pre-diabetes and severe diabetes: islet structure and staining density and distributions of insulin and glucagon in AyK-M mice are similar to those in AyL mice but are slightly worse. In contrast, all these changes in AyK-S mice are similar to those in $\mathrm{db} / \mathrm{db}$ mice but are less severe. Importantly, PC activity levels were paralleled with $\beta$-cell function and mass during the pathogenesis of T2DM, strongly suggesting that $\mathrm{PC}$ is associated with insulin secretion and $\beta$-cell proliferation.

In summary, we found that islet PC activity and insulin secretion were increased in $\mathrm{AyL}$ and $\mathrm{AyK}-\mathrm{M}$ mice and were reduced in AyK-S and $\mathrm{db} / \mathrm{db}$ mice; additionally, islet morphological aberrations and a clear association between PC activity and hyperglycemia/ $\beta$-cell function/mass have been demonstrated. An in vitro study has shown that islet PC activity was inhibited by high glucose but not by fatty acid palmitate. Our results suggest that increased islet PC activity might play an important role in $\beta$-cell adaptation to insulin resistance, and the reduction of islet PC activity in type 2 diabetic mice might be a consequence of mild hyperglycemia and a cause of severe hyperglycemia. We have summarized our hypothesis in Fig. 6. Having said this, the results in our current study would not be strong enough to draw a precise conclusion; $\beta$-cell $P c$ transgenic or knockout mouse models would be excellent tools for future studies. Because PC activity is sensitive to mild hyperglycemia indicated in this study, strict control of blood glucose levels would be very important to prevent the onset of frank diabetes in the patients with pre-diabetes or mild T2DM.

\section{Declaration of interest}

The authors declare that there is no conflict of interest that could be perceived as prejudicing the impartiality of the research reported.

\section{Funding}

This work was supported by grants from the National Institutes of Health (P20 RR/DE17702 from the COBRE Program of the National Center for Research Resources, and 1R01DK077624-01 from NIDDK) and the American Diabetes Association (Junior Faculty Award). This project was also supported by a grant (6931) from The Research Institute for Children, Children's Hospital at New Orleans.

\section{Acknowledgements}

We wish to thank Mr Naeem Uddin for critical reading of the manuscript.

\section{References}

Ahren B, Gudbjartsson T, Al Amin AN, Martensson H, Myrsen-Axcrona U, Karlsson S, Mulder H \& Sundler F 1999 Islet perturbations in rats fed a high-fat diet. Pancreas 18 75-83.

Bahl JJ, Matsuda M, DeFronzo RA \& Bressler R 1997 In vitro and in vivo suppression of gluconeogenesis by inhibition of pyruvate carboxylase. Biochemical Pharmacology 53 67-74.

Bajaj M, Berria R, Pratipanawatr T, Kashyap S, Pratipanawatr W, Belfort R, Cusi K, Mandarino L \& DeFronzo RA 2002 Free fatty acid-induced peripheral insulin resistance augments splanchnic glucose uptake in healthy humans. American Journal of Physiology. Endocrinology and Metabolism 283 E346-E352.

Baverel G, Conjard A, Chauvin MF, Vercoutere B, Vittorelli A, Dubourg L, Gauthier C, Michoudet C, Durozard D \& Martin G 2003 Carbon 13 NMR spectroscopy: a powerful tool for studying renal metabolism. Biochimie 85 863-871.

Brune B, Dimmeler S \& Lapetina EG 1992 NADPH: a stimulatory cofactor for nitric oxide-induced ADP-ribosylation reaction. Biochemical and Biophysical Research Communications 182 1166-1171.

Bruning JC, Winnay J, Bonner-Weir S, Taylor SI, Accili D \& Kahn CR 1997 Development of a novel polygenic model of NIDDM in mice heterozygous for IR and IRS-1 null alleles. Cell 88 561-572.

Busch AK, Cordery D, Denyer GS \& Biden TJ 2002 Expression profiling of palmitate- and oleate-regulated genes provides novel insights into the effects of chronic lipid exposure on pancreatic beta-cell function. Diabetes $\mathbf{5 1}$ 977-987.

Cline GW, LePine RL, Papas KK, Kibbey RG \& Shulman GI $2004{ }^{13} \mathrm{C}$ NMR isotopomer analysis of anaplerotic pathways in INS-1 cells. Journal of Biological Chemistry 279 44370-44375.

DeFronzo RA \& Prato SD 1996 Insulin resistance and diabetes mellitus. Journal of Diabetes and its Complications 10 243-245. 
Dmitriev LF 2001 Activity of key enzymes in microsomal and mitochondrial membranes depends on the redox reactions involving lipid radicals. Membrane and Cell Biology 14 649-662.

Farfari S, Schulz V, Corkey B \& Prentki M 2000 Glucose-regulated anaplerosis and cataplerosis in pancreatic beta-cells: possible implication of a pyruvate/citrate shuttle in insulin secretion. Diabetes 49 718-726.

Gabriely I, Ma XH, Yang XM, Rossetti L \& Barzilai N 2002 Leptin resistance during aging is independent of fat mass. Diabetes 51 1016-1021.

Gotoh M, Maki T, Satomi S, Porter J, Bonner-Weir S, O'Hara CJ \& Monaco AP 1987 Reproducible high yield of rat islets by stationary in vitro digestion following pancreatic ductal or portal venous collagenase injection. Transplantation 43 725-730.

Han J, Xu J, Epstein PN \& Liu YQ 2005 Long-term effect of maternal obesity on pancreatic beta cells of offspring: reduced beta cell adaptation to high glucose and high-fat diet challenges in adult female mouse offspring. Diabetologia 48 1810-1818.

Hasan NM, Longacre MJ, Stoker SW, Boonsaen T, Jitrapakdee S, Kendrick MA, Wallace JC \& MacDonald MJ 2008 Impaired anaplerosis and insulin secretion in insulinoma cells caused by small interfering RNA-mediated suppression of pyruvate carboxylase. Journal of Biological Chemistry 283 28048-28059.

Infante JP \& Huszagh VA 1998 Analysis of the putative role of 24-carbon polyunsaturated fatty acids in the biosynthesis of docosapentaenoic (22:5n-6) and docosahexaenoic (22:6n-3) acids. FEBS Letters 431 1-6.

Jensen MV, Joseph JW, Ilkayeva O, Burgess S, Lu D, Ronnebaum SM, Odegaard M, Becker TC, Sherry AD \& Newgard CB 2006 Compensatory responses to pyruvate carboxylase suppression in islet beta-cells. Preservation of glucose-stimulated insulin secretion. Journal of Biological Chemistry 281 22342-22351.

Jetton TL, Liu YQ, Trotman WE, Nevin PW, Sun XJ \& Leahy JL 2001 Enhanced expression of insulin receptor substrate-2 and activation of protein kinase B/Akt in regenerating pancreatic duct epithelium of 60\%-partial pancreatectomy rats. Diabetologia 44 2056-2065.

Jonas JC, Sharma A, Hasenkamp W, Ilkova H, Patane G, Laybutt R, Bonner-Weir S \& Weir GC 1999 Chronic hyperglycemia triggers loss of pancreatic beta cell differentiation in an animal model of diabetes. Journal of Biological Chemistry 274 14112-14121.

Khan A, Ling ZC \& Landau BR 1996 Quantifying the carboxylation of pyruvate in pancreatic islets. Journal of Biological Chemistry 271 2539-2542.

Kido Y, Burks DJ, Withers D, Bruning JC, Kahn CR, White MF \& Accili D 2000 Tissue-specific insulin resistance in mice with mutations in the insulin receptor, IRS-1, and IRS-2. Journal of Clinical Investigation 105 199-205.

Kjorholt C, Akerfeldt MC, Biden TJ \& Laybutt DR 2005 Chronic hyperglycemia, independent of plasma lipid levels, is sufficient for the loss of beta-cell differentiation and secretory function in the $\mathrm{db} / \mathrm{db}$ mouse model of diabetes. Diabetes $\mathbf{5 4}$ 2755-2763.

Labarca C \& Paigen K 1980 A simple, rapid, and sensitive DNA assay procedure. Analytical Biochemistry 102 344-352.

Liu YQ, Tornheim K \& Leahy JL 1998 Fatty acid-induced beta cell hypersensitivity to glucose. Increased phosphofructokinase activity and lowered glucose-6-phosphate content. Journal of Clinical Investigation 101 1870-1875.

Liu YQ, Tornheim K \& Leahy JL 1999 Glucose-fatty acid cycle to inhibit glucose utilization and oxidation is not operative in fatty acid-cultured islets. Diabetes 48 1747-1753.

Liu YQ, Jetton TL \& Leahy JL $2002 \beta$-Cell adaptation to insulin resistance. Increased pyruvate carboxylase and malate-pyruvate shuttle activity in islets of nondiabetic Zucker fatty rats. Journal of Biological Chemistry 277 39163-39168.

Liu YQ, Moibi JA \& Leahy JL 2004 Chronic high glucose lowers pyruvate dehydrogenase activity in islets through enhanced production of long chain acyl-CoA: prevention of impaired glucose oxidation by enhanced pyruvate recycling through the malate-pyruvate shuttle. Journal of Biological Chemistry 279 7470-7475.

Liu YQ, Han J, Epstein PN \& Long YS 2005 Enhanced rat beta-cell proliferation in $60 \%$ pancreatectomized islets by increased glucose metabolic flux through pyruvate carboxylase pathway. American Journal of Physiology. Endocrinology and Metabolism 288 E471-E478.
Lu D, Mulder H, Zhao P, Burgess SC, Jensen MV, Kamzolova S, Newgard CB \& Sherry AD $2002{ }^{13} \mathrm{C}$ NMR isotopomer analysis reveals a connection between pyruvate cycling and glucose-stimulated insulin secretion (GSIS). PNAS 99 2708-2713.

MacDonald MJ 1995a Feasibility of a mitochondrial pyruvate malate shuttle in pancreatic islets. Further implication of cytosolic NADPH in insulin secretion. Journal of Biological Chemistry 270 20051-20058.

MacDonald MJ $1995 b$ Influence of glucose on pyruvate carboxylase expression in pancreatic islets. Archives of Biochemistry and Biophysics 319 128-132.

MacDonald MJ 2003 Export of metabolites from pancreatic islet mitochondria as a means to study anaplerosis in insulin secretion. Metabolism 52 993-998.

MacDonald MJ, Efendic S \& Ostenson CG 1996a Normalization by insulin treatment of low mitochondrial glycerol phosphate dehydrogenase and pyruvate carboxylase in pancreatic islets of the GK rat. Diabetes 45 886-890.

MacDonald MJ, Tang J \& Polonsky KS $1996 b$ Low mitochondrial glycerol phosphate dehydrogenase and pyruvate carboxylase in pancreatic islets of Zucker diabetic fatty rats. Diabetes 45 1626-1630.

MacDonald MJ, Longacre MJ, Langberg EC, Tibell A, Kendrick MA, Fukao T \& Ostenson CG 2009 Decreased levels of metabolic enzymes in pancreatic islets of patients with type 2 diabetes. Diabetologia $\mathbf{5 2}$ 1087-1091.

Menendez J, Delgado J \& Gancedo C 1998 Isolation of the Pichia pastoris PYC1 gene encoding pyruvate carboxylase and identification of a suppressor of the pyc phenotype. Yeast 14 647-654.

Nicholls LI, Ainscow EK \& Rutter GA 2002 Glucose-stimulated insulin secretion does not require activation of pyruvate dehydrogenase: impact of adenovirus-mediated overexpression of PDH kinase and PDH phosphate phosphatase in pancreatic islets. Biochemical and Biophysical Research Communications 291 1081-1088.

Palmer ND, Langefeld CD, Campbell JK, Williams AH, Saad M, Norris JM, Haffner SM, Rotter JI, Wagenknecht LE, Bergman RN et al. 2006 Genetic mapping of disposition index and acute insulin response loci on chromosome 11q: the Insulin Resistance Atherosclerosis Study (IRAS) Family Study. Diabetes 55 911-918.

Sheline CT \& Choi DW 1998 Neuronal death in cultured murine cortical cells is induced by inhibition of GAPDH and triosephosphate isomerase. Neurobiology of Disease 5 47-54.

Shoelson SE, Lee J \& Goldfine AB 2006 Inflammation and insulin resistance. Journal of Clinical Investigation 116 1793-1801.

Unger RH 1995 Lipotoxicity in the pathogenesis of obesity-dependent NIDDM. Genetic and clinical implications. Diabetes 44 863-870.

Wallace JC 1985 Pyruvate carboxylase. In CRC Series in Enzyme Biology, pp 5-63. Eds DB Keech \& JC Wallace. Boca Raton: CRC Press.

White MF 2003 Insulin signaling in health and disease. Science $\mathbf{3 0 2}$ 1710-1711.

Xu J, Han J, Epstein PN \& Liu YQ 2006 Regulation of PDK mRNA by high fatty acid and glucose in pancreatic islets. Biochemical and Biophysical Research Communications 344 827-833.

Xu J, Han J, Long YS, Epstein PN \& Liu YQ 2008 The role of pyruvate carboxylase in insulin secretion and proliferation in rat pancreatic beta cells. Diabetologia 51 2022-2030.

Zhou YP, Ostenson CG, Ling ZC \& Grill V 1995 Deficiency of pyruvate dehydrogenase activity in pancreatic islets of diabetic GK rats. Endocrinology 136 3546-3551.

Zhou YP, Berggren PO \& Grill V 1996 A fatty acid-induced decrease in pyruvate dehydrogenase activity is an important determinant of beta-cell dysfunction in the obese diabetic $\mathrm{db} / \mathrm{db}$ mouse. Diabetes 45 580-586.

Zhou YP, Cockburn BN, Pugh W \& Polonsky KS 1999 Basal insulin hypersecretion in insulin-resistant Zucker diabetic and Zucker fatty rats: role of enhanced fuel metabolism. Metabolism 48 857-864.

Received in final form 3 November 2009

Accepted 12 November 2009

Made available online as an Accepted Preprint 12 November 2009 